FACTA UNIVERSITATIS

Series: Law and Politics Vol. 15, N 3, 2017, pp. 191 - 200

https://doi.org/10.22190/FULP1703191T

Review Article

\title{
IS THE LOGIC OF LAW IN CONTRAST TO CHRISTIAN VALUES?*
}

\author{
UDC 340.13:27
}

\section{Marko Trajković}

Faculty of Law, University of Niš, Republic of Serbia

\begin{abstract}
Is it possible for logic of law to squeeze out Christian values, given that the nihilism towards values leads towards the rejection of the major role of the law, which is the protection and realization of values? Is the actual goal of the legal norm, as part of law and logical legal system turned into a command, to establish the behavior which carries out the Christian values it contains? Is the constitution, the law or some other act as the embodiment of the legal norm, really based on certain social and legal values? As opposed to the law, there is a man able to ponder and wonder. Does he live in accordance with the legal norms only out of fear of punishment? Would it be possible for the government to establish the legal system which would be totally based on the fear of sanctions? Can that kind of legal system ever become a stable whole, or might it be destroyed by itself? Is the reason for the failure of the system of the state and law insufficiently centralized government, for example, or the lack of Christian values in their very grounds? The answer to the question posed by St. Thomas Aquinas depends on the answers to the previously posed questions. The question posed by St. Thomas Aquinas is: is the law made only for the evil and the wicked? However, it would be naive to rely on the tendency of correlation between human behavior and his moral principles. The entire human history confirms the result. We are well equipped to find reasons for what we do, but we are not so good when we are to do something for which we see good reasons, for which the reasons are obvious. We often say to our children: "Do as I tell you", forgetting that they watch and copy exactly what we do. One of the ways to strengthen the bonds between values-attitudes-behavior is to apply signs for encouragement which are supposed to empower the real behavior.
\end{abstract}

Key words: value, law, system, legal norm

Received September 26 $6^{\text {th }}, 2017$ / Accepted October $4^{\text {th }}, 2017$

Corresponding author: Prof. dr. Marko Trajković

Faculty of Law, University of Niš, Trg Kralja Aleksandra 11, 18000 Niš, Republic of Serbia

E-mail: marko@prafak.ni.ac.rs

* This paper is a result of research conducted within the project "Harmonizing the Serbian Legislation with the Law of European Union", funded by the Faculty of Law in Nis for the period 2013-2018. 


\section{HUMAN EXISTENCE AND LAW}

How can a legal norm and Christian values influence the change of behavior? This is the question that can be expected because human existence without Christian values, in its very core, cannot be considered. Inconsistencies towards values are unpleasant and dangerous since values are central for knowing oneself and others. Therefore, inconsistencies in values are significant for change of behavior. What man feels is hardship, that is to say, disorder between how he sees himself and the real behavior. If man's behavior does not fulfill value standards which are given and which a person has set for himself, it brings about inconsistencies.

Human existence, without values, would be like animal survival and not like free Christian life. For these reasons, we can say that there cannot be legal issues without values considered.

Man and his life remain pure organic processes if we exclude values. Thus, Max Weber and Leo Strauss point to our attitude towards values as indispensable. Weber insists on the role which values play in the social science (Strauss, 1992: 38-39). Looking at it from the ontological point of view, the existence of man without values is impossible. If law was devoid of values, it would be crippled in its human core.

In case man really did not take part in realization of Christian values, he would not be in a position to exercise his humanity. Man's deeds would have all the features of unquenchable longing for the establishment of the relation between our reality and values only in case of the realization of values. This would refer to law as well, which is also the value product of the human spirit. Therefore, it is necessary to divert attention to the axiological surface of law and then to the legal system as a whole. If values were excluded from the legal system, as the creation of the human spirit, as a reason for its existence, law would turn into a pure formal and legal way of existence of the legal norm. Since the realization of law lies in the very construction of law, it is necessary to establish the place of law in the world of Christian values.

The best way to recognize a man is to know what kind of future he is creating. His creation of future is based on values. The formulation of legal norm is also a way of forming the future, the future of nations, not of a person. Thus, the extent to which legal norm has influence the future can be unforeseeable. That's why it is so important to incorporate values into a legal norm. Christian values are moved into the center of life. They cause lasting belief.

Christian values stand for standards which rule our behaviors. They help us measure and judge situations we encounter in life. At the same time, values have the function of motivation, which is manifested as our strive towards achieving values (for example, we strive to be honest). The reason for this complete faith in values, most probably comes out of our understanding of values as standards for behavior. That is why, although we cannot embrace them completely, they do not allow partial solutions.

Only Christian values do not allow partial solutions. In contrast, law does, especially positive law. This legal problem can be solved via axiology of law, i.e. by the recognition that law must be based on values, as well as on their application in law.

By opening the value path of law, we can finally hope for a better and fairer law that rests on deeper foundations than the will of a sovereign.

Neither can the very disposition of the legal norm rely on its binding force if its source lies in a sovereign's will. The binding force must be derived from much more powerful and more reliable source, such are values. To that extent can we discuss the binding force of a legal norm, which is necessary for the application of a legal norm. Nevertheless, the legal norm can 
also be applied by a sanction, which is not the accepted mode of its application, but the imposition of the legal norm which has not been previously accepted.

Hence, the sanction cannot be the foundation of a legal norm's binding force, only values can. The value path of law wants the law to finally be imbued with values, which will empower it to be accepted and applied. Without it, law begins to limp on its path and, eventually and alongside, it succumbs to challenges. What withstands all the challenges are the values given by the Creator .

Such given Christian values infuse the law with the necessary power and represent an inexhaustible resource to which law turns when in doubt. They represent the ultimate source of law, legal norms, legal relations, and, ultimately, the legal system on the whole.

Nothing is more powerful than such given values, and nothing withstands time and human temperament as the values whose foundation is in the will of the Creator, while everything else is relative and perishable.

Our reality has faced the dramatic changes in the moral attitudes of people. In the light of these changes, we are trying to consider the issue of the ethical aspect of the competent patient's request to die and the physician's decision about it by examining both Christian and philosophical and legal approach. Our consideration of this issue would be based on questioning of the basic human values. We would like to emphasize the fact that human dignity - as the basic value- is not determined by external causes and does not depend on whether a person is healthy or sick. Human dignity is something integral, essential and inalienable. Thus, human dignity springs from the quality of human life as a unique human being, as a spiritual and physical being endowed with reason and freedom, self-responsibility and the possibility of self-defining - in case we accept that a man is created in the image and likeness of God. The historical prism of considering this problem is widely different; there were complete justifications of these requests but there were also those who criticized them. Even nowadays, this issue brings about disputes in the field of morality and law; with the emphasis that decriminalization of this may lead to a slippery slope.

Our answer to the question what the Christian view of man is based on, that is to say, what the Christian anthropology is based on, would be the following: a man is meant for eternity, and that can explain the sense of existence and the meaning of human longing. We begin with the standpoint that from the Christian point of view there is no such a thing as a life without value. We look at human life as a God's gift, therefore, as something that God defined as such. Taking this into account, human freedom is not without grounds, and is not without responsibility. Thus, man is not a pure coincidence and he does not live in absolute autonomy. . It is important to determine that the physician's position should be defined by law so that it facilitates an already difficult position of having to decide about someone's life. This would determine whether or not there are grounds for legal prosecution, although Christian, moral dilemma always remains, which we insist upon.

Thus, we divert attention to the Christian approach to human life and dignity according to which man does not assign life, therefore, man cannot take away life, regardless of the hardship.

This part of the paper points to the level of practice in which value-based foundation of a legal norm is primarily necessary. Euthanasia, as a practical issue we encounter, may best illustrate the issue of the absence of values in a legal norm, as well as in the foundations of a legal system.

For us, this issue represents a sort of exit from the framework of theoretical observation of the issue of value-based foundation of a legal norm. It confirms the necessity to accept 
values in the creation of law, and in its application, especially because we associate the issue of euthanasia with both totalitarian and democratic states.

The issue of moral-value aspect of a patient's request to die, and the doctor's decision regarding the request, represent a touchstone of public argumentation within a legal system of any state. Therefore, it indicates the moral-value attitude concerning the formulization of the law.

We believe that the path of European secularization needs a Christian-moral correction, especially with issues that occupy the public attention. Although we start from Christian beliefs, we also have appreciation for, according to Jürgen Habermas , a religiously discordant man. Actually, the appreciation represents a binding notion of the contemporary Rule of Law. However, religiously discordant man is also obliged to self-critically determine the relation between mind and religion.

Therefore, the consideration of the issue of a patient's request to die and of the doctor's decision regarding the request leads us to the question: what sustains our world?

Values which, in Immanuel Kant's view, are contained within themselves - human life and human dignity, are derived from the essence of human existence and are, thus, inviolable for all those who possess such an essence.

In Immanuel Kant's realm of purposes, everything has either a price or a dignity. What has a price is such that its position can be occupied by something else as its equivalent. On the contrary, that which is more sublime than any price, that which does not allow for any equivalent, is human dignity. According to Kant, general human inclinations and needs have a market price. Affective price is in the possession of our enjoyments, in the aimless game of our powers. Dignity is the only condition under which something is capable to create a purpose per se; it possesses neither a relative value, nor price; rather, it possesses internal value. According to Kant, morality represents an only condition under which an intellective being can be a purpose per se. Based upon that morality, it is possible to be a legislative member of the realm of purposes. Dignity, according to Kant, can only reside within man, under the condition that man is capable of morality. Human life is, therefore, the main basis and the most visible sign of moral value. However, even as such, it is sometimes in conflict with some other value, particularly in this case, with the value of dignified death. Therefore, an axiological conflict emerges when the value of dignified death appears on the scale of values. The value of dignified death, or ortotanasia. must not be regarded as the formation of law, a formation of a legal system in precise terms; it refers to the ethical reality in which an ethical request is made. At the same time, the notion does not refer specifically to death, but to a form of death.

Leaving aside the etymological origin and the value-based aspect, which in various periods of human civilization had a competent patient's request to die, we believe that situations of euthanasia are those in which the value of human life seems to be in the state of such darkening of annihilation, due to which a therapy, which anticipates death, proves to be the best alternative. Therefore, a man deduces that it is better to terminate the life flow and, thus, reach death more quickly, in order to relieve the sufferings that lead to agony. In "Déclaration sur l'euthanasie", passed in 1980 by Congregatio pro Doctrina Fidei, a view is taken that euthanasia should represent an action or omission which, by its intent and its nature, causes death, with the aim of relieving any pain. The definition was taken by the enclitics "Evangelium Vitae".

We believe, in accordance with the opinion of Pope Pius XII, that euthanasia represents an evil that is contradictory to natural and divine law, which embedded in every man's soul, 
and that the doctor's acceptance of the patient's request to die represents the violation of the most noble sentiments for humanity. It is even worse when euthanasia is being praised as a product of human progress, as something useful for the common welfare.

If we accept that the master of life is not man, but God, then we have to accept the following: a doctor as a private entity cannot undertake an action which would lead to euthanasia, and the patient cannot grant the doctor with more rights than he himself possesses. And, since he is not an absolute master of himself, his body and his spirit, he cannot request such thing as a mercy killing. This further implies that neither one can request to be subjected to euthanasia, nor any social or state authority in a contemporary legal state can approve or accept it. It is actually a violation of the divine law, the violation of human dignity and an offence against life. Here, we share the opinion that these situations serve to make somebody become nobody. Accordingly, man cannot be deprived of his significant attribute - that he is made in God's image. By the virtue of such dignity, any man, at any period of his life, even in the situation of serious illness, always preserves the right and responsibility to respect the foundations of such dignity. Thus, neither from biological standpoint can man be reduced to a living inhuman, i.e. he cannot be dehumanized. Therefore, if we seriously consider that man is rational in his essence, and that the genuine value of man lies in his acceptance of God, then it is clear that his dignity is not only associated with his generic specifications. His capabilities, for example, his mind, might be lost, but dignity remains forever, it is eternal because it was received from God. Therefore, man is unconditionally loved and confirmed by God, and, being such, he acquired dignity.

This makes the conclusion by Pope John Paul II more valid, when, by starting from such premises, he defines our reality as cultura di morte (Paolo II, 2004: 444). The cultura di morte represents a vision in which the ethical meaning of human life is lost. In such a reality, a patient does not understand that he is not an absolute master of his life, but that God is; similarly, the doctor does not understand that no man can authorize him to commit something like that.

Thus, by Christian reasoning on the value of life and dignity, it is possible to preserve dignity from the pervasive violence, and not from so anonymous forces, as it used to be in pervious periods, but from a man himself, as the highest force that acts against himself. Therefore, the cooperation between mind and religion should prevent the moral legitimatization of such violence.

\section{ABSOLUTE FREEDOM AND DESTRUCTION OF FREEDOM AND DIGNITY}

The development of man's powers, which are too often destructive, imposes the issue of moral control of power. An absolute freedom, which has no respect for life, represents a destruction of freedom as well. Thus, the value of life is darkened. Attacks on the value of human life are evident. On the one hand, the value of life is emphasized but, on the other hand, human life is not inviolable in reality. Such a situation can be overcome only if we defeat the ambiguity of life by means of mind and religion's consistency, i.e. if the value of human life is justified at its foundation. Only thus can we avoid a slippery slope.

The slippery slope represents an example of the consequences of accepting euthanasia. Murders, directly performed by doctors, which are rationalized by the notion of life which is not worth living (lebensunwertes Leben ), prove that the cases of mercy killings of severely deformed infants and children, being a first immoral step, lead to the slippery slope. 
Today, it is difficult to determine what lebensunwertes Leben exactly is from the perspective of motives of euthanasia. What should be missing in the quality of human life for us to reject it? It seems to vary from person to person, if it is regarded from the perspective of positive attitude towards euthanasia.

On the one hand, there is still a connection between totalitarian state regimes and proeuthanasia ideologies while, on the other hand, we still have examples of democratic legal systems which are open to such motives of euthanasia. Therefore, it is not only associated to totalitarian state regime, nor is it just an example of former negative practice of such states. The link between legal system and euthanasia still exists today. The link is reflected in the absence of the concept of a person's transcendence. For, when the value is reduced, which is closely linked to the affirmation of the existence of God as a Person, the autocracy of a man over another man is reflected in a political leader of an absolutistic regime or in the instances of individualism.

Once we take the first immoral step, something bad is being liberated in human nature, and it can no longer be controlled. Previously, a moral rule used to restrict that harmful force, but now there is an exception which may serve as a benchmark; so, the absolute moral rule disappears. Ultimately, this opens the path for an absolute immoral freedom.

Thus, once we perform a minor modification of a moral rule, other modifications become inevitable, due to the requirement of mind for the consistence in the similar treatment of similar cases. That is why Norman Fost, professor of pediatrics in Wisconsin and a medical ethicist, believes that in any society where the patient's request to die is legally accepted, it would be applied so broadly that the situation would get out of control (Vard, 1990).

That is why Michael Swago was arrested in 2000 as a serial killer of his patients. He was charged with and sentenced for the murder of three patients in the state of New York. It was estimated, in the course of the trial, that Swago killed at least 60 patients. His diary, which was used in trial, revealed that he committed murders due to the excitement derived from the power to kill and because of the sweet intoxicating scent of murders behind closed door (LeDuff, 2000: 29).

It is exactly the evil in human nature, which we claim may be realized by a legal death assisted by doctors. This further implies that, once released, the destructive principle will swallow up the whole personality and control all its actions. Such destructive impulses and destructive ideas cannot remain limited or directed only towards one subject or several subjects; they have to expand inevitably and to be directed against the entire surroundings, including one's own group and one's own self.

In that respect, Nat Hentoff, a disability rights lawyer, who opposes euthanasia, believes that the actions of Dr. Jack Kevorkian, or Dr. Death, as well as the decriminalization of doctor-assisted death in the Netherlands and Oregon, represent an insane devaluation of life (Hentoff, 1987). Namely, in November 1994, citizens of Oregon accepted the Death with Dignity Act, which enabled the doctor to legally provide medical assistance in dying by prescribing adequate medicines to the patient.

In June1990, Janet Adkins asked the retired pathologist Jack Kevorkian to help her die. She was 54 years old, she was suffering from Alzheimer disease where, from the first symptoms, life expectance amounts to 10 years on the average. On June $4^{\text {th }} 1990$, he drove her to a public park in the northern Auckland County in Michigan. He named his device mercitron - it consisted of three bottles; the first contained a saline solution, the second contained a powerful sedative thiopental (which is released by the patient himself/herself; 
thereupon, a timer triggers a switch which soon activates the infusion of potassium chloride. Thiopental made Janet Adkins unconscious, and potassium chloride killed her a minute later. She had painless heart attack while she was deeply asleep; the whole process took less than 6 minutes. The local district attorney filed charges against Jack Kevorkian for murder, but the local judge dropped the case because, in Michigan, there was no law against a suicide assisted by another; yet, he ordered Jack Kevorkian not to use mercitron ever again. In autumn 1991, he assisted a double suicide of Sherry Miller and Marjoire Wanz, one was diagnosed with multiple sclerosis, and the other suffered chronic pain in the area of vagina and pelvis. The charges were dropped again, but his medical license was suspended in Michigan in November 1991, which meant that he could no longer procure sodium pentothal, so he had to use carbon monoxide. In June 1995, he opened an assisted-suicide clinic, but he was soon evicted by the proprietor. Until 1998, he had helped 100 patients to die. Jack Kevorkian was charged with murder of the first degree, and was convicted for the second degree murder. Michigan judge Jessica Kuper sentenced Jack Kevorkian on April $13^{\text {th }} 1999$, saying: "Consider yourself hindered." For the death of the next patient, seventy years old Jack Kevorkian was sentenced to 10-25 years of imprisonment. He was released on June $1^{\text {st }} 2007$, promising that he would no longer perform euthanasia; he committed 130 murders in total.

In 1973, the Medical Association of the Netherlands agreed with Dutch attorneys that doctors would not be tried for murder if they comply with the following guidelines:

- Only competent patients can request to die;

- Patient's requests must be repeated, unambiguous, unpressured and documented;

- Doctor must consult another doctor to get an impartial opinion, and

- Patient must suffer unbearable pain or suffering, without probability of improvement.

These guidelines were further formalized in 1984 .

By 1990, the Netherlands had become the place where one could see whether the fulfillment of a patient's wish to die would lead to barbarianism. The Netherlands Remmetie Commission studied the data on medical practice and reported in 1990 that 1000 deaths were induced without compliance with the prescribed guidelines. Therefore, although the guidelines were prescribed to especially facilitate the legal aspect of criminal liability of doctors, they were not obeyed entirely. How can we explain that? One way is the very absence of an absolute moral law, i.e. the presence of an absolute immoral freedom. These guidelines lost their significance with the first murder that was contrary to the prescribed rules. They were supposed to limit human actions in the Netherlands, but they actually legitimized acts contrary to ethics. Therefore, instead of preventing the practice, they certainly contributed to sliding down the slippery slope. Moreover, it was determined in 1991 that approximately 1040 people died as a result of involuntarily euthanasia in that country. Have the doctors forgotten the guidelines? Who were they prescribed for? Therefore, this means that the analogy, as a means of interpretation of regulations, will be skillfully and maliciously applied, and that it is already being applied even to the incompetent patients. In doing so, they quote the argument of alleviation from suffering. We consider such an argument, which is one of the phantom notions, is sufficient to justify all cases and, thus, lead to a widely accepted and applied practice of euthanasia.

The Supreme Court of the Netherlands decided in 1994 that even unbearable mental sufferings may justify a voluntary euthanasia. First, imagine what the phrase "unbearable mental sufferings" may refer to and how arbitrarily it may be used. Who judges what unbearable mental sufferings are? Furthermore, what is the quantitative meaning of unbearable, how subjective is it? Therefore, such an arbitrary notion has been taken from 
reality and transferred into a legal norm by means of the process of justiciabilisation. Now, imagine a lawyer who, within the interpretation as a unique process, uses an extensive interpretation of the notion of unbearable mental suffering. Have we already started rolling down the slope? We think that the better question would be: where does the rolling end? We once again reply that there is no end actually. Our mind has a need to treat similar cases in a similar manner. Therefore, we will not stop until we achieve the ultimate aim - cultura di morte.

Doctor-assisted death was made completely legal in the Netherlands in April 2001. The law, which was passed in both legislative houses, did not include the amendment aimed at entitling 12 to 15 years old terminally ill children to the same right. Such an amendment, which some authors deemed to be controversial but which we find absolutely immoral, confirms the previous attitudes. Where are the guidelines now? Legally speaking, the path from the submission of legal amendments to their adoption is very short. Even if they were not previously accepted, now they are formulated, only waiting for a favorable political climate to be put into effect. They, somehow informally, entered the procedure. Although such a view is considered unscientific by proceduralists, we believe that the legislative practice demonstrates a completely different reality. Once an attitude is formalized, it starts living its own life and will eventually be realized. We are afraid that it would be too late to react then.

Now, we want to associate the view on unbearable sufferings with the proposal referring to 12 to 15 years old children who request to die. Who wants such a reality? How are we to be assured of the life of the young when, in a future situation that may as well occur within our lifetime, they may be legally entitled to terminate their lives? Instead of being a shield and a barrier, law becomes the supporter of evil. Law provides us with the option to no longer consider the life of the young, given that they, due to the unbearable sufferings, may request to die. Someone else will take pity on them.

$$
* * *
$$

Legalization of euthanasia would add an entire new murder category, so that private persons would be actually entitled to kill each other in order to alleviate sufferings. We do not want to extend the category of homicide, where man can kill, even in the name of charity. It would change the nature of law and open the path to malpractice. We would, thus, incorporate the evil which exists in reality into legal norms. Thus, law would officially become a source of evil. We would provide the opportunity for the process of justiciablization to convert a norm which contains evil into a legal norm that could guarantee the realization of a value.

Then, despite all dilemmas and fears ahead of us when we discuss such a topic, we would introduce phantom notions that would utterly shatter inconsistent human instinct for good. Then, Pandora's Box might become the basis for the construction of new views within the legal matter, and especially within criminal law matter. Therefore, when we would move to the level of law, it would also undermine the grounds and fundamental inheritance of criminal law matter. When we would define the source of law, we would have to emphasize that it is eventually - evil.

Legally speaking, even if we utilize the hermeneutic method, we would not be able to provide justification for the decriminalization of this type of homicide. Hermeneutics of 
law, which wants law to finally be open towards life facts, would not provide a valid result in this case.

As an example of a lawyer's interpretation, which is in contrast with the moral-value interpretation, we incite an unnecessary creation of a subtle distinction between voluntary euthanasia, where a patient requests a doctor to give him a lethal drug, and the assisted suicide, where a competent person may decide himself to take a lethal substance which was prescribed by a doctor, but not given by him. In moral-value terms, we believe that there is no need to make a distinction between these two situations, for a doctor certainly knows that if it is prescribed, the drug is available, and that the expected outcome is death. Are the notions culprit and moral culprit, criminal act and moral or immoral act, and criminal sanction and moral sanction identical in this case? How far is this solution from ethical responsibility for one's own actions? Finesses of legal reflection on reality and the interpretation of legal regulations distance us far away from the ethics of life and human dignity. It occasionally seems that law is directly opposed to values due to its resourcefulness. And, instead being empowered by morality, positive law avoids it or, even worse, denies it with its temporary power. Ultimately, we do not see the need for such a distinction, except to protect doctors from prosecution and their conscience, and that is insufficient to blur the ethical perspective of the problem. Nevertheless, despite this, the Hippocratic Oath, which is considered a source of medical ethics and which, thereby, represents a basic regulation for a doctor, states that doctors are forbidden to kill patients. Nowadays, few medical schools use the original version, and particularly the pagan curse at the end of it. Therefore, the Hippocratic Oath unambiguously states that a doctor shall not give a lethal drug to anyone if he asks for it, nor shall he suggest anything similar.

If we legalized euthanasia, we would completely exit the framework of natural law and would move to legal tailoring of reality, which would not be based upon natural law or upon values of human life and dignity. We would forget about the value basis of law, which constitutes the binding force of a legal norm. If we exclude values as the basis of the binding force of a legal norm, and include cultura di morte as a basis, holistic legal system will collapse. Thereby, it would not collapse due to the lack of centralization, but due to its bases that would not be valid. Unfortunately, it would not be the first time.

Actions of a doctor must be enlightened and empowered by a legal value, such as legal stability, but we must also realize the overall value of human life and dignity. Therefore, we should construct a contemporary legal system which would guarantee both legal stability and human dignity.

Nowadays, man is capable of grasping a new form of power; he has actually descended deep into the abyss of power. The question arises: what should be done? We should critically enlighten the violence, which is legally and morally legitimized, via the bond between mind and religion, and disclaim hasty conclusions on what a man is and where his limits are.

Human mind must be advised, considers Pope Benedict XVI. Moreover, he believes that, just as there are pathologies in religion, there is also pathology of mind, which, according to him, mankind is not aware of.

Regarding the request to die, a man has to search for landmarks by listening to both mind (science) and religion. There is no other way except for listening and cleansing of mind and religion. It is necessary due to the world situation tired of rationality, which is referred to by Pope Benedict XVI. The necessary cleansing of mind and religion, as we have mentioned, occurs due to pathologies that exist in religion and within a mind, and which are, according to Pope Benedict XVI, dangerous and must be overcome by the 
divine light of reason that will have to be ready to learn to hear great religious traditions of mankind. Concerning the situations concerning the request to die that is addressed to a doctor, we do not need the union of mind and religion; , we rather need the consideration of the issues of natural and positive law relation. As an exampe of cooperation between religion and the mind, we would mention the rejection of therapeutical persistance by the Catholic church, as well as the acceptance of pain therapy, i.e. usage of analgetics.

In order to discard cutura di morte, to value life and respect human dignity, we must oppose the mens eutanasica, which represents a manifestation of immorality of a contemporary state's legal system, where, in particular situations, it is decided that there is a life which is not worth living. Behind such a mentality of euthanasia, there are violations of human dignity, as well as a legal collapse of the human dignity ethics. Who will measure the bad consequences of such a mentality?

\section{REFERENCES}

Hentoff, N. (1987), Decision on Euthanasia Will Create a Slippery Slope, Village Voice.

LeDuff, C. (2000), Prosecutors Say Ex-Doctor Killed Becouse it Thrilled Him, NYT.

Paolo II, G. (2004), Evangeium vitae, Enchadrion della Famiglia, Documenti magisteriali e pastorali su famiglia e vita 1965-2004, Bologna.

Strauss, L. (1992), Natural Right and History, Chicago \& London.

Vard, M. (1990), Experts Consider Legal and Ethical Aspect of Helping Americans Die, Milwaukee Journal, Wisconsin.

Translated by: Mila Trajković

\section{DA LI JE LOGIKA PRAVA SUPROTNA HRIŠĆANSKIM VREDNOSTIMA?}

Da li je moguće da pravo istisne vrednosti, pošto nihilizam prema vrednostima vodi direktno ka njihovom odbacivanju u pravu koje bi valjalo da ih štiti i omogući njihovu primenu. Da li pravna norma kao elemanat prava koji se pretvara u komandu ima za zadatak da uspostavi ponašanje koje sadrži vrednosti? Da li potom ustav ili zakonski akti imaju za svoju osnovu drutšvene i pravne vrednosti.

Nasuprot pravu, stoji čovek koji može da se pita da li on živi u skladu sa pravnim normama samo iz straha? Da li je moguće uspostaviti pravni sistem koji u celini počiva na sankcijama? Da li takav pravni sistem može da postane stabilan ili može da uništi sam sebe? Da li je razlog za propast pravnih sistema nedovoljno centralizovana vlast ili nedostatk vrednosti u njihovim osnovama?

Odgovor se može naći u pitanju svetog Tome Akvinskog, da je pravo ostavljeno samo za zle $i$ opake? Naravno, bilo bi veoma naivno sve zasnovati na vezi ljudskog ponašanja i moralnih principa. Celokupna ljudska istorija to pokazuje. Mi smo dovoljno dobro opremljeni da nađemo razloge za ono što činimo, ali nismo toliko dobri da činimo ono zašta vidimo da postoje dobri i objektivni razlozi. Tako veoma često kažemo našoj deci da čine ono što mi kažemo, ali zaboravljamo da oni kopiraju naše ponašanje. Jedan od puteva da se učvrsti veza između ljudskog ponašanja i pravnih normi jeste da se uspostavi veza između vrednosti, ponašanja i pravne norme.

Ključne reči: vrednosti, pravo, sistem, pravna norma 